\title{
Public Satisfaction Survey On Registration Services Of Hindu Religion Education Institutions In Bali Province
}

\author{
Ni Komang Sutriyanti ${ }^{1}$, I Made Dharmawan ${ }^{2}$ \\ ${ }^{12}$ Universitas Hindu Negeri I Gusti Bagus Sugriwa Denpasar \\ 1nikomangsutriyanti@gmail.com
}

\begin{abstract}
The Regulation issuance of the Religion Minister of the Republic Indonesia No. 56/2014 that concerning on Hindu Religion Education in formal and non-formal education forms requires the Directorate General of Hindu Community Guidance to organize a registration service. The quality of the registration service needs to be surveyed as an evaluation of the implementation of public services. The subjects in this survey research are leaders / managers of formal and non-formal pasraman in Bali who already have registration list in 2020. The aspects that reviewed to determine service satisfaction are based on 14 minimum elements as indicators that must exist as a basis for measuring IKM on public service performance that are in accordance to the Ministerial Decree No. PAN. 25 of 2004. The sampling technique was carried out using disproportionate stratified random sampling, the data collection technique used an attitude scale as the main data and interviews and document studies as supporting data. Data were analyzed descriptively which were the community satisfaction score was sought first, the score was then adjusted to the criteria table. Overall, the level of community satisfaction with registration service of Hindu religious education institutions was very high. This can be proven by the average community satisfaction score of 82.75 (very high). In addition, if it was reviewed based on aspects of public service, among the 14 (fourteen) aspects of service, there were 4 (four) aspects that got very high satisfaction, namely discipline of officers, fairness of service, courtesy of officers and environmental comfort, while other aspects were in high satisfaction criteria. If it was reviewed by regency / city, all districts / cities in the Bali province got satisfaction score with very high criteria. Factors that affected public satisfaction with the sign service of Hindu religion education institutions include planning, leadership, monitoring of reliability, responsiveness, assurance, empathy, tangible, and tangible factors, certainty and service costs.
\end{abstract}

Keywords: Community Satisfaction; Registration Service; Hindu Religion Education Institutions

\section{Introduction}

The development of science and technology is increasingly rapid, the demands of the community in terms of service are increasingly stringent, so that the unit providing public services is required to fulfill the expectations of the community in making service improvements. The quality of public services is a major indicator of good governance, from the central government to local governments. Even the Ministry of PANRB encourages the improvement of the quality of public services through awards for government agencies that carry out development and innovation of public services.

In 2014 the Minister of State Apparatus Empowerment and Bureaucratic Reform Regulation No. 16 of 2014 concerning Guidelines for Community Satisfaction Surveys on the Implementation of Public Services, replacing the Ministerial Decree Empowerment of State Apparatus Number: Kep/25/M.PAN/2/2004 concerning Public Guidelines for 
Compiling the Community Satisfaction Index of Government Service Unit Service Units, in which it is regulated about activities that must be carried out by public service providers in providing quality services (Minister of Empowerment). State Apparatus and Bureaucratic Reform, 2014). One of the activities that must exist is to conduct a Community Satisfaction Survey. Related to this research, researchers are more likely to use the 14 elements of the community satisfaction index in the Decree of the Minister of Administrative Reform Number: Kep/25/M.PAN/2/2004 because it is considered in line with the object of research (Minister of Administrative Reform and Bureaucratic Reform, 2004). ). It is further said that "The satisfaction index can also be useful if the measurement is continuous. Because it will be reflected in the increasing or decreasing community satisfaction index" (Wibisono, 2018).

Based on several studies conducted by academics and bureaucrats on public services in Indonesia, it turns out that the condition is still often considered not good and satisfactory. This is shown from the conclusion made by Agus Dwiyanto, et al in GDS (Governance and Decentralization) 2002 in 20 provinces in Indonesia regarding the performance of public services stating "in general the practice of public service delivery is still far from the principles of good governance". Then the performance of public bureaucratic services in Indonesia, based on a report from The World Competitiveness Yearbook in 1999, was in the group. Countries that have the lowest competitiveness index among the 100 most competitive countries in the world (Dwiyanto, Agus, 2008: 11). It was further stated that "the bad impression of public services has always been the image attached to the service provider institution. Public services are always identified with inaction, injustice, and high costs. Not to mention in terms of service ethics where the behavior of service providers is expressive and does not reflect the spirit of good service" (Dzulfadli, 2019).

The Directorate General of Hindu Community Guidance at the Ministry of Religion of the Republic of Indonesia has the duty of formulating and implementing policies and technical standardization in the field of Hindu religious guidance. Regulation of the Minister of Religion of the Republic of Indonesia No. 10 of 2010 states that the Directorate General of Hindu Community Guidance has the following functions: 1) Formulation of policies in the field of Hindu community guidance; 2). Implementation of policies in the field of Hindu community guidance 3) Formulation of norms, standards, procedures, and criteria in the field of Hindu community guidance; 4) Providing technical guidance and evaluation in the field of Hindu community guidance; and 5) Implementing the administration of the Directorate General of Hindu Community Guidance. One of the services provided by the Directorate General of Hindu Community Guidance is the registration of Hindu religious educational institutions. The service process is carried out through several stages involving relevant institutions in each region such as the Regional Office of the Ministry of Religion of the Province and the Ministry of Religion of the Regency / City in each proposer.

Based on the Regulation of the Religion Minister of the Republic of Indonesia No. 56 of 2014 namely Hindu Religious Education is a formal and non-formal education in the pasraman forum. Formal Pasraman is a tiered-structured pasraman education that consisting of Pratama Widya Pasraman (TK), Adi Widya Pasraman (SD), Madyama Widya Pasraman (SMP) and Utama Widya Pasraman (SMA). Non-formal pasraman is an educational path outside the formal pasraman which is carried out in a structured manner. The establishment of a formal pasraman in Bali of course refers to regulations as a juridical basis. This is considered important, because the establishment of a formal pasraman can be declared as a formal forum in order to produce Hindu human resources with superior and character. In an effort to produce superior Hindu human resources, it is not enough 
just to be based on ideas, without being based on clear concepts that refer to legislation. Therefore, the existence of a formal pasraman in Bali is a strategic basis for developing Hindu human resources to be legalized in a formal form as stated in a ministerial regulation (Sutriyanti, 2020: 242). It was further stated that Pasraman designed a special Hindu Religion-based learning that provides students with experience in exploring religious knowledge in an effort to increase students' values and personality (Amiruddin Henry Praherdhiono, 2019).

The demands of the user community for Hindu religious institutions to provide increasingly advanced and satisfying services are getting stronger, this is possible because science and technology which are the "main menu" in Hindu religious institutions are also advancing rapidly. On the other hand, in presenting the menu as pleasant administrative services, it is hoped that the community as consumers can learn well and get satisfaction. Customer satisfaction has become a central concept in business and management discourse (Tjiptono, F., \& Chandra, 2005: 11).

The results of measuring community satisfaction can contribute positive thoughts to the Directorate General of Hindu Community Guidance at the Religion Ministry of the Republic of Indonesia in realizing a religious institution that is credible and trusted by the community. In connection with the services provided, it is deemed necessary to carry out "Community Satisfaction" measurements and research. The Community Satisfaction Survey aims to obtain feedback on the performance/quality of services provided by the Directorate General of Hindu religious education to the community in order to improve performance/quality of service in the registration process for Hindu religious education institutions.

\section{Method}

This research is a survey research conducted from June to October 2020 in the Province of Bali, where the subjects in this study are the leaders/managers of formal and non-formal pasraman in Bali who already have a registration mark in 2020. The aspects reviewed to determine service satisfaction are based on on 14 minimum elements as indicators that must exist as a basis for measuring IKM on the performance of public services in accordance with Ministerial Decree PAN No. 25 of 2004.

The sampling technique used was a disproportionate stratified random sampling technique, namely sampling by determining the number of samples if the population was stratified but less proportional (Sugiyono, 2010). Firtsly, Researchers conducted a mapping with related to the number of Hindu religious education institutions in each district/city in the Bali province. If in a district/city there are Hindu religious education institutions with a number of 3 , the whole will be taken as a sample. However, if the number is above 3 , the researcher takes a sample of $50 \%$ from the total number of Hindu religious education institutions in the district/city which is carried out randomly. The data collection technique uses an attitude scale as the main data, interviews and document studies as supporting data. The data were analyzed descriptively where the community satisfaction score was sought first, the score was then adjusted according to the criteria table.

\section{Results and Discussion}

1. Results of the Analysis of the Community Satisfaction Survey on the Registration Service of the Directorate General of Hindu Community Guidance at Hindu Religious Education Institutions in Bali Province

The results of the research are presented as an analysis of the overall community satisfaction survey, an analysis per aspect of public services and an analysis of community 
satisfaction at the district/city level. The results of the analysis of the overall community satisfaction survey are presented in Table 1 as follows.

Table 1. Results of Overall Community Satisfaction Survey Analysis

\begin{tabular}{|l|l|l|l|}
\hline No & Type of Score & Score & Criteria \\
\hline $\mathbf{1}$ & High Score & 100,00 & Very high \\
\hline $\mathbf{2}$ & Low Score & 62,85 & High \\
\hline $\mathbf{3}$ & Average Score & 82,75 & Very high \\
\hline
\end{tabular}

Source: Data processed in 2020

The data in Table 1 states that the community as a whole has a very high satisfaction with the registration service for Hindu religious education institutions. It can be seen based on the average score of the community satisfaction survey of 82.75 which is classified as very high. In addition, the distribution of community satisfaction score data is also carried out based on criteria. The distribution results are presented in Table 2 as follows.

Table 2. Distribution of Community Satisfaction Survey Scores into the Criteria Table

\begin{tabular}{|l|l|l|l|}
\hline No & Category & Frequence & Percentage \\
\hline 1 & Very high & 25 & $86,20 \%$ \\
\hline 2 & High & 4 & $13,80 \%$ \\
\hline 3 & Low & 0 & $0,00 \%$ \\
\hline 4 & Very low & 0 & $0,00 \%$ \\
\hline
\end{tabular}

Source: Data processed in 2020

The data in Table 2 corroborates the data in Table 1 which states that most or around $86.20 \%$ of the people stated that they were very satisfied with the service for registering Hindu religious education institutions provided by the Ministry of Religion. Researchers also conducted an analysis of community satisfaction with aspects of public services. The results of the analysis are presented in Table 3 as follows.

Table 3. Results of Community Satisfaction Survey Analysis by Aspect

\begin{tabular}{|l|l|l|l|l|l|}
\hline No & Aspect & $\begin{array}{l}\text { Highest } \\
\text { score }\end{array}$ & $\begin{array}{l}\text { Lowest } \\
\text { score }\end{array}$ & $\begin{array}{l}\text { Average } \\
\text { score }\end{array}$ & Zone \\
\hline 1 & Service Procedure & 5,00 & 3,00 & 4,13 & $\begin{array}{l}\text { High } \\
\text { satisfaction }\end{array}$ \\
\hline 2 & $\begin{array}{l}\text { Service } \\
\text { requirement }\end{array}$ & 5,00 & 2,00 & 4,00 & $\begin{array}{l}\text { High } \\
\text { satisfaction }\end{array}$ \\
\hline 3 & $\begin{array}{l}\text { Clearing service } \\
\text { officer }\end{array}$ & 5,00 & 2,00 & 4,17 & $\begin{array}{l}\text { High } \\
\text { satisfaction }\end{array}$ \\
\hline 4 & $\begin{array}{l}\text { Service Officer } \\
\text { Discipline }\end{array}$ & 5,00 & 3,00 & 4,20 & $\begin{array}{l}\text { Very high } \\
\text { satisfaction }\end{array}$ \\
\hline 5 & $\begin{array}{l}\text { Officer's } \\
\text { Responsibilities }\end{array}$ & 5,00 & 3,00 & 4,03 & $\begin{array}{l}\text { High } \\
\text { satisfaction }\end{array}$ \\
\hline 6 & $\begin{array}{l}\text { Ability of service } \\
\text { officer }\end{array}$ & 5,00 & 3,00 & 4,00 & $\begin{array}{l}\text { High } \\
\text { satisfaction }\end{array}$ \\
\hline 7 & $\begin{array}{l}\text { Service Speed } \\
\text { High } \\
\text { satisfaction }\end{array}$ \\
\hline 8 & Service Justice & 5,00 & 3,00 & 4,24 & $\begin{array}{l}\text { Very high } \\
\text { satisfaction }\end{array}$ \\
\hline 9 & Officer Courtesy & 5,00 & 4,00 & 4,48 & $\begin{array}{l}\text { Very high } \\
\text { satisfaction }\end{array}$ \\
\hline 10 & Service Fairness & 5,00 & 3,00 & 4,00 & $\begin{array}{l}\text { High } \\
\text { satisfaction }\end{array}$ \\
\hline
\end{tabular}




\begin{tabular}{|c|l|l|l|l|l|}
\hline 11 & $\begin{array}{l}\text { Service Fee } \\
\text { Certainty }\end{array}$ & 5,00 & 3,00 & 4,13 & $\begin{array}{l}\text { High } \\
\text { satisfaction }\end{array}$ \\
\hline 12 & $\begin{array}{l}\text { Certainty of } \\
\text { Service Schedule }\end{array}$ & 5,00 & 3,00 & 4,03 & $\begin{array}{l}\text { High } \\
\text { satisfaction }\end{array}$ \\
\hline 13 & $\begin{array}{l}\text { Environmental } \\
\text { Comfort }\end{array}$ & 5,00 & 3,00 & 4,34 & $\begin{array}{l}\text { Very high } \\
\text { satisfaction }\end{array}$ \\
\hline 14 & Service Security & 5,00 & 3,00 & 4,13 & $\begin{array}{l}\text { High } \\
\text { satisfaction }\end{array}$ \\
\hline
\end{tabular}

Source: Data processed in 2020

The data in Table 3 shows that the Ministry of Religion is able to provide services for registering Hindu religious educational institutions that satisfy the community. Even some aspects of service are in the zone of very high satisfaction, namely the discipline and courtesy of service officers, service justice and environmental comfort. In addition, an analysis of community satisfaction surveys at the district/city level was also conducted. The results of the analysis of the community satisfaction survey at the district/city level in Bali province can be seen in Table 4 and Table 5 as follows.

Table 4. Results of Community Satisfaction Survey Analysis of Each Regency/City

\begin{tabular}{|l|l|l|l|l|l|}
\hline No & District/city & $\begin{array}{l}\text { Highest } \\
\text { score }\end{array}$ & $\begin{array}{l}\text { Lowest } \\
\text { score }\end{array}$ & $\begin{array}{l}\text { Average } \\
\text { score }\end{array}$ & Criteria \\
\hline 1 & Jembrana & 98,57 & 80,00 & 86,19 & Very high \\
\hline 2 & Klungkung & 85,71 & 85,71 & 85,71 & Very high \\
\hline 3 & Badung & 100,00 & 75,71 & 85,42 & Very high \\
\hline 4 & Buleleng & 90,00 & 74,28 & 82,38 & Very high \\
\hline 5 & Gianyar & 100,00 & 62,85 & 82,14 & Very high \\
\hline 6 & Karangasem & 82,85 & 81,42 & 82,14 & Very high \\
\hline 7 & Denpasar & 81,42 & 81,42 & 81,42 & Very high \\
\hline 8 & Bangli & 85,71 & 75,71 & 80,00 & Very high \\
\hline 9 & Tabanan & 88,57 & 67,14 & 79,52 & Very high \\
\hline
\end{tabular}

Source: Data processed in 2020

Table 5. Distribution of Community Satisfaction Survey Scores into the Criteria Table In Regency/City

\begin{tabular}{|c|c|c|c|c|c|}
\hline \multirow[t]{2}{*}{ No } & \multirow[t]{2}{*}{ Kabupaten/Kota } & \multicolumn{4}{|l|}{ Kriteria } \\
\hline & & $\begin{array}{l}\text { Sangat } \\
\text { Tinggi }\end{array}$ & Tinggi & Rendah & $\begin{array}{l}\text { Sangat } \\
\text { Rendah }\end{array}$ \\
\hline 1 & Jembrana & $100,00 \%$ & $0,00 \%$ & $0,00 \%$ & $0,00 \%$ \\
\hline 2 & Klungkung & $100,00 \%$ & $0,00 \%$ & $0,00 \%$ & $0,00 \%$ \\
\hline 3 & Badung & $100,00 \%$ & $0,00 \%$ & $0,00 \%$ & $0,00 \%$ \\
\hline 4 & Buleleng & $75,00 \%$ & $25,00 \%$ & $0,00 \%$ & $0,00 \%$ \\
\hline 5 & Gianyar & $66,67 \%$ & $33,34 \%$ & $0,00 \%$ & $0,00 \%$ \\
\hline 6 & Karangasem & $100 \%$ & $0,00 \%$ & $0,00 \%$ & $0,00 \%$ \\
\hline 7 & Denpasar & $100 \%$ & $0,00 \%$ & $0,00 \%$ & $0,00 \%$ \\
\hline 8 & Bangli & $100 \%$ & $0,00 \%$ & $0,00 \%$ & $0,00 \%$ \\
\hline 9 & Tabanan & $66,67 \%$ & $33,34 \%$ & $0,00 \%$ & $0,00 \%$ \\
\hline
\end{tabular}

Source: Data processed in 2020

Table 4 and Table 5 show that at the district/city level, the community has high satisfaction with the service of making a registration card for Hindu religious education institutions. In fact, some districts/cities are able to achieve a satisfaction score of up to $100 \%$. 


\section{Community Satisfaction with the Registration Service of the Directorate General of Hindu Community Guidance at Hindu Religious Education Institutions in Bali Province}

The results of the study stated that the level of community satisfaction with the registration service of Hindu religious educational institutions in Bali Province was in the very high category. This is evidenced by the average score of the community satisfaction survey which is worth 82.75 . If the score is converted into criteria, it is classified as very high. This is reinforced by data on the percentage of community satisfaction. The results of the analysis stated that $86.20 \%$ of the research sample stated that they had high satisfaction with the registration service for Hindu religious education institutions in the province of Bali, which in fact was provided by the Ministry of Religion through the Directorate General of Hindu Community Guidance. For more details can be seen in graph 1 below.

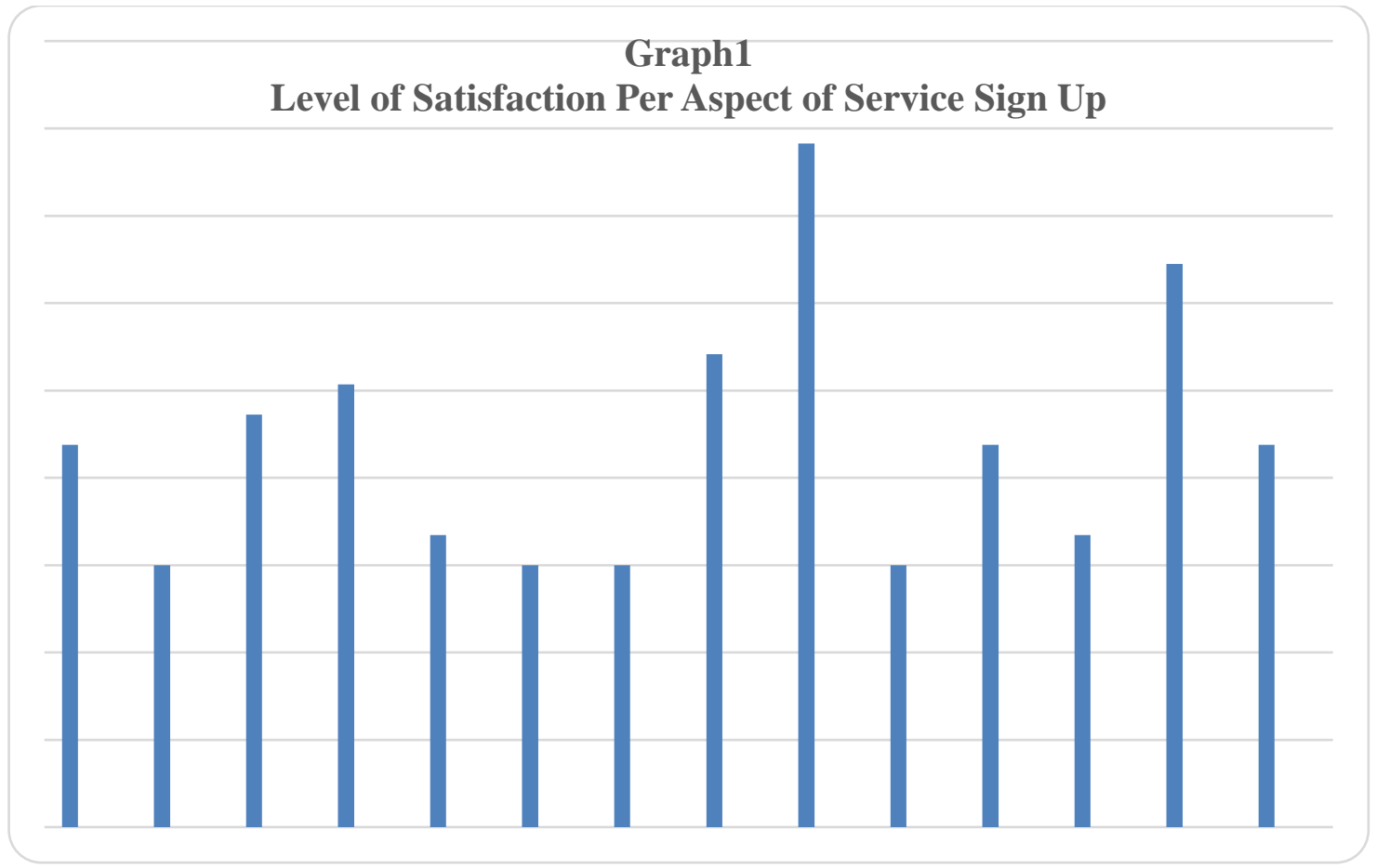

Source: Data processed in 2020

The predicate of high and very high satisfaction was also obtained when analyzing per aspect of public services. There are 14 (fourteen) aspects of public service that are concerning in this research, namely service procedures, service requirements, clarity of service officers, discipline of service officers, responsibilities of officers, ability of service officers, speed of service, service fairness, courtesy of officers, fairness of service, certainty of service costs, certainty of service schedules, environmental comfort and service security. Among the 14 (fourteen) aspects of the service, there are 4 (four) aspects that get satisfaction in very high category, namely officer discipline, service justice, staff courtesy and environmental comfort.

The highest score of the community satisfaction index is in the politeness aspect of the officers. Then followed by aspects of environmental comfort and fairness of service. The aspects that get the lowest community satisfaction scores are aspects of service requirements, the ability of service personnel and speed of service, which each of them have the same score of 4.0. Although these three aspects have the lowest satisfaction scores among other aspects of public services, these scores are still in the high satisfaction zone. 
The researcher also conducted an analysis of community satisfaction at the district/city in the Bali province. The results of the analysis state that all districts/cities get a very high level of satisfaction from the community related to the registration service of Hindu religious educational institutions. In fact, there are 2 (two) districts that get the maximum score from the research sample, namely Badung and Gianyar districts. In addition, the difference in the average score of community satisfaction in each district/city is also not too large, which is in range score of 0.4 to 3.04. This indicates that there is no disparity in service quality that is too large between regencies/cities in Bali province. For more details, the level of community satisfaction based on 14 indicators can be seen in graph 2 below.

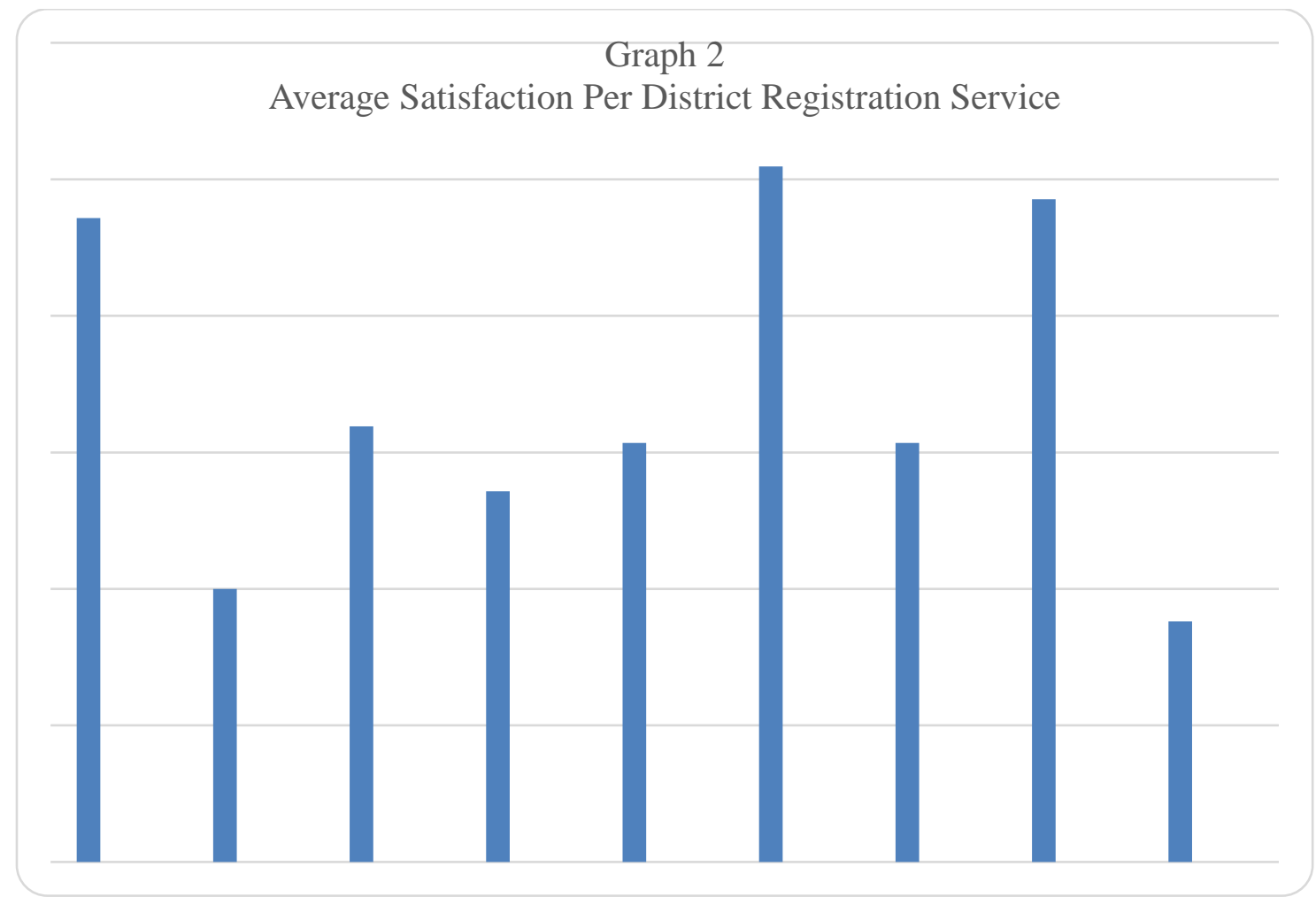

Source: Data processed in 2020

If sorted by rank, Jembrana districts, Klungkung and Badung are first to third ranked with an average score of 86.19 each; 85.71 and 85.42 . The lowest score was obtained by Tabanan district with an average score of 79.52. Then, if a frequency distribution analysis is carried out, there are 6 (six) districts/cities in which the entire research sample gives a very high satisfaction score in the category. The regencies/cities in question include Jembrana, Klungkung, Badung, Karangasem, Denpasar and Bangli.

In each district/city, an analysis of public services in each of its aspects is also carried out. After the analysis, the politeness aspect of the officers got a very high average satisfaction score in all districts/cities in Bali. The results of the analysis also state that none of the aspects of public service receive a low or critical score in each district/city in Bali province. If reviewed based on regencies/cities, researchers found that there are no districts/cities in Bali Province that get very high satisfaction scores on all aspects of public services. For more details can be seen in graph 3 below. 


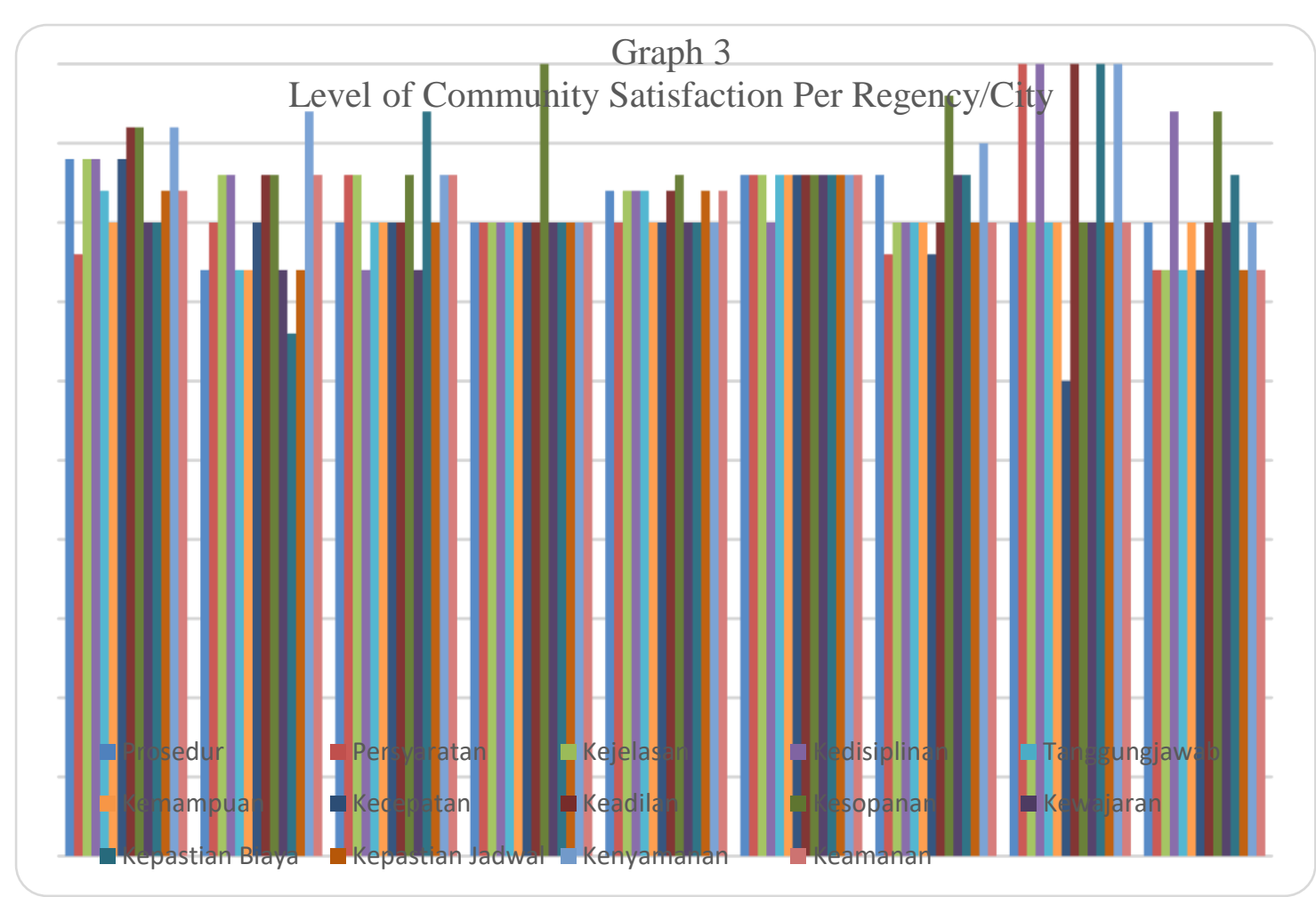

Source: Data processed in 2020

Districts/cities that get the highest satisfaction score on aspects of public services are obtained by Jembrana district. The district, which is located in the western part of the Bali island, has succeeded in obtaining a very high level of satisfaction in 13 (thirteen) aspects of public service. Only one aspect of public service in the district is in high category, namely the discipline of service officers. If the ranking of public services aspects is carried out by district/city, then Badung district has the highest community satisfaction score on aspects of service procedures, clarity of service officers, service discipline and speed of service. The highest score for aspects of service requirements, politeness of officers, certainty of service costs and environmental comfort was obtained by Klungkung district. The city of Denpasar obtained the highest community satisfaction score in the aspect of officer courtesy. The service security aspect received the highest score in three districts, namely Jembrana, Buleleng and Bangli. The other four aspects, namely the responsibility of officers, the ability of officers, fairness of service and certainty of service schedules, received the highest score in Jembrana district.

There are records relating to community satisfaction with service of registering Hindu educational institutions. The note mentioned that there are still aspects of public services that only get enough scores in some districts/cities. In Klungkung district, the Speed of Service aspect only gets an average score of 3.00, which means that it is in sufficient category of public service zones. In addition, the sufficient category zone is also found in the aspect of Service Cost Certainty in Bangli district. This is certainly a reflection material for all of us so that in the future these aspects can get a better community satisfaction score.

\section{Factors Affecting Community Satisfaction to the Registration Service of Hindu Religious Education Institutions}

Public service is one of the things that must be provided by the government to the community in order to carry out the government's role as a public service provider. Government officials are responsible for providing the best service to the community in 
order to create community welfare (Rohmad, 2017: 26). Service excellence is shaped through four closely related pillars: speed, accuracy, friendliness and convenience of service. Service excellence cannot be realized if there is one weak pillar (Fadhil Junery, 2020). The government should always improve the quality and quantity of public services on an ongoing basis in order to realize the concept of good governance and community satisfaction.

Public services are carried out by all levels of government, both central and regional. For this reason, it is a must for state apparatus as public servants who seek community satisfaction" (Suksma Sinaga, 2020). One form of public service carried out by the central government is the issuance of a register of Hindu religious educational institutions, which in this case is carried out by the Ministry of Religion through the Directorate General of Hindu Community Guidance. The results of the study stated that overall the community had very high satisfaction with the registration service of Hindu religious education institutions. In addition, the community also expressed very high satisfaction with aspects of the registration service for Hindu religious education institutions, such as procedures, requirements, comfort and ability of officers to provide services and other aspects of public services.

Several factors influence the high level of community satisfaction with the registration service of Hindu religious educational institutions. The first factor is because of planning. The Ministry of Religion at the central, provincial and regional levels already has a good plan regarding registration services. This is evidenced by the existence of standard operating procedures (POS) for registration services. In this procedure it is very clear the flow of services and the parties involved in the service. Good planning will certainly produce good performance and will be accompanied by stakeholder (community) satisfaction (Rohmad, 2017: 24).

The second factor is the factor of leadership and supervision. All leaders in the ranks related to registration services, namely from the Regency/City Ministry of Religion (Kankemenag) Office, the Regional Office of the Ministry of Religion of the Province of Bali and the Directorate General of Hindu Guidance, have the same commitment to improve the quality of services for the advancement of Hindus in particular and all people in generally. Therefore, the leaders in each work unit routinely carry out control or supervision in order to maintain the quality of registration services.

Factors that also has a role in determining community satisfaction are reliability, responsiveness, assurance, empathy, and tangible factors (Yuliarmi \& Riyasa, 2007: 9). The reliability factor referred is the timeliness of officers in serving the community, the presence of officers at the service location and the fairness of officers in providing services. Based on the results of interviews with several research samples, they stated that registration service officers were always at the service location when they needed service and even during breaks the officers still took their time to provide services. The officers also act neutrally and do not show favoritism in providing services so that the community feels satisfied.

The influencing factor is also related to responsiveness. The registration service officer acts quickly in providing the registration service. The registration process recommendation service process is relatively short, only 8 hours 30 minutes if studied based on existing standard operating procedures. This was further strengthened by comments from people who had received services saying that the service time was good, in accordance with procedures, not complicated if the files were complete and the officers were responsive in serving.

Confidence (assurance) and empathy also contribute to the high satisfaction of the community in the registration service. Service personnel are always friendly and courteous 
in providing these services and adhere to the principle of thorough work. One sample stated that when they received the service, the officers showed a friendly, polite, friendly and patient attitude. In addition, the officers also provided treats in the form of drinks and sweets so that it fostered a relaxed atmosphere. Therefore, it is not surprising that the results of the service analysis aspects of the politeness of officers get the highest score from other aspects.

Tangible factors also have an effect. Based on observations, the location for getting registration services has a comfortable feel and service equipment has begun to accommodate information technology. This will certainly make people feel comfortable and at home when they are at the registration service location.

In order to maintain the consistency of information on Systems, Mechanisms, and Procedures, the community expects the Systems, Mechanisms and Procedures to be carried out online. The online mechanism is believed by the public to make the information they receive steady because the online system is relatively the same for anyone who accesses and reads it whenever they access and read it. The online system is also believed by the public to reduce the time to leave the main activity in order to take care of the service (Syaifullah, 2019: 78). It was further stated that "in terms of the relationship between the demands for the achievement of satisfaction of public information services and the progress of information technology which is growing rapidly, public information services are it should be transformed into online-based public information with content still referring to public information service regulations" (Zaky Maulana, 2018).

Other factors that also contribute to community satisfaction regarding registration services are the certainty factor and service costs. The certainty referred is certainty regarding the time of service and service personnel. Service times are served according to working days and hours, so that people have guidelines and can take the time to take care of registration services. Certainty is also related to the party in charge. Related to registration services, the officers involved are the one-stop integrated service division (PTSP), the Head of Hindu Religious Education, the Head of Hindu Religious Education and the Regional Office of the Ministry of Religion. The requirements for obtaining the service are also definite and there are not many files. Requirements to get a registration service only require a proposal, letter of recommendation, structure and composition of the board, having Articles of Association and Bylaws, statement letter, notarial deed and being registered with OSS. In addition, this service is also free of charge so that it adds to the satisfaction of the community when the service is provided.

Some suggestions were also given by the community regarding registration services. First, the service time is getting shorter. Second, they want the service flow to be shortened, that is, it is enough for the Ministry of Religion of the districts/cities only. This is certainly a challenge for the Ministry of Religion so that in the future it can improve the quality of registration services so that they are more satisfying and according to people's tastes, especially in the current era everything is based online.

\section{Conclusion}

Overall, the level of community satisfaction with the registration service for Hindu religious education institutions is at a very high criterion. This can be proven by the average community satisfaction score of 82.75 (very high). In addition, if examined based on aspects of public services, among the 14 (fourteen) service aspects, there are 4 (four) aspects that get satisfaction in the very high category, namely officer discipline, service justice, officer courtesy and environmental comfort while other aspects are in high satisfaction criteria. . If it is reviewed by district/city, then all districts/cities in the province 
of Bali get a very high satisfaction score with criteria. responsiveness, assurance, empathy, tangible factors, certainty and service costs.

Some recommendations that can be given by researchers based on the results of this study are as follows: 1) Registration services for Hindu religious education institutions to adopt a full online and paperless system so that the service process becomes faster, environmentally friendly and does not need to queue at the service location. 2) Service time and signage service flow to be shortened. 3) Regencies/Cities that are ranked at the bottom of the list service quality must begin to improve so that in the next period the quality of service will be better and the competition for service quality will be more competitive. 4) Service aspects that have received very high satisfaction scores must be maintained and aspects that are in high criteria must be improved so that later they can be included in the very high category. 5) There is a need for further research on other services provided by the Ministry of Religion to Hindus in particular and to all people in general.

\section{References}

Amiruddin Henry Praherdhiono, M. (2019). Pelaksanaan Program Sekolah Pasraman Sasana Putra Pandawa Dalam Peningkatan Sikap Budi Pekerti di Lingkungan Keluarga Hindu Desa Sedaeng Kecamatan Tosari Kabupaten Pasuruan. Jurnal Kajian Teknologi Pendidikan, 2(3), 188-194.

Bungin, B. (2019). Metodologi Penelitian Kuantitatif (Komunikasi, Ekonomi, dan Kebijakan Publik Serta Ilmu-Ilmu Sosial Lainnya). Prenadamedia Group.

Dwiyanto, Agus, D. (2008). Reformasi Birokrasi Publik di Indonesia. Gadjah Mada University Press.

Dzulfadli, A. M. (2019). Survey Indeks Kepuasan Masyarakat (IKM) Terhadap Layanan di Kabupaten Konawe Selatan Provinsi Sulawesi Tenggara. Jurnal Teropong Aspirasi Politik Islam, 15(2), 228-239.

Fadhil Junery, M. (2020). Pengaruh Kualitas Layanan Terhadap Tingkat Kepuasan Masyarakat Pada Kantor Imigrasi Bengkalis. Jurnal Ilmiah Ekonomi Kita, 9(1), $102-114$.

Menteri Agama. (2014). Peraturan Menteri Agama Nomor 56 Tahun 2014.Tentang Pendidikan Agama dan Keagamaan Hindu.

Menteri Agama. (2017). Keputusan Menteri Agama Nomor 656 Tahun 2017 Tentang Indikator Kinerja Utama Kementerian Agama.

Menteri Pendayagunaan Aparatur Negara dan Reformasi Birokrasi. (2004). Keputusan Menteri Pendayagunaan Aparatur Negara Nomor: KEP/25/M.PAN/2/2004 Tentang Pedoman Umum Penyusunan Indeks Kepuasan Masyarakat Unit Pelayanan Instansi Pemerintah.

Menteri Pendayagunaan Aparatur Negara dan Reformasi Birokrasi. (2014). Peraturan Menteri Pendayagunaan Aparatur Negara dan Reformasi Birokrasi Republik Indonesia Nomor 16 Tahun 2014 Tentang Pedoman Survei Kepuasan Masyarakat Terhadap Penyelenggaraan Pelayanan Publik.

Morissan. (2012). Metode Penelitian Survey. Kencana.

Rohmad, Z. (2017). Faktor-Faktor yang Mempengaruhi Kepuasan Masyarakat dalam Pelayanan Publik di Dinas Kependudukan dan Catatan Sipil Kabupaten Magetan. Habitus, 1(1).

Sugiyono. (2010). Metode Penelitian Pendidikan Pendekatan Kuantitatif, Kualitatif dan $R \& D$. Alfabeta.

Suksma Sinaga, M. (2020). Melalui Survei Kepuasan Masyarakat: Tingkatkan Kualitas Layanan Pendidikan. Jurnal Ilmu Administrasi Publik, 8(2), 265-274. 
Sutriyanti, N. K. (2020). Persepsi Masyarakat Hindu Terhadap Keberadaan Pasraman Formal Di Bali. Jurnal Kajian Bali (Journal of Bali Studies), 10(1), 235-260. https://doi.org/10.24843/JKB.2020.v10.i01.p11

Syaifullah, D. H. (2019). Kepuasan Masyarakat Terhadap layanan Keagamaan oleh Direktorat Jenderal Bimbingan Masyarakat (Ditjen Bimas) Buddha. SMaRT, 05(01).

Tim Penulis. (2016). Survey Kepuasan Masyarakat Pada Pelayanan Publik Pemerintah Kota Surabaya Tahun 2016.

Tjiptono, F., \& Chandra, G. (2005). Service, Quality \& Satisfaction. Andi Offset.

Wibisono, A. (2018). Analisis Kepuasan Masyarakat Dalam Layanan Pendidikan. Jurnal Bisnis \& Akuntansi, 8(2), 102-111.

Yuliarmi \& Riyasa. (2007). Analisis Faktor-Faktor Yang Mempengaruhi Kepuasan Pelanggan Terhadap Pelayanan PDAM Kota Denpasar. Buletin Studi Ekonomi, 12(1).

Zaky Maulana, A. (2018). Kajian Tingkat Kepuasan Masyarakat Terhadap Layanan Informasi Publik Online di Pemerintah Kota Banjarmasin. Jurnal Kebijakan Pembangunan, 13(2), 107-114. 